\title{
El tratamiento con antibióticos por patologías ocasionales se asocia a menor riesgo de desarrollo de un primer infarto.
}

Antibiotics and risk of subsequent first- time acute myocardial infarction. Meier C, Derby L, Jick S y col. JAMA 1999: 281:427-431

\section{Objetivo}

Determinar si el uso previo de antibióticos disminuye la posibilidad de desarrollar un primer infarto agudo de miocardio.

\section{Diseño}

Estudio caso control retrospectivo.

Lugar

Reino Unido. Red de 350 Médicos Generales (General Practice Research Database).

\section{Participantes}

Del total de pacientes incluidos en la base de datos de la GPRD detectaron 3315 infartos en menores de 75 años a lo largo de 5 años, y lo aparearon ${ }^{*}$ con 13139 controles ( 4 controles por cada paciente con infarto) por criterios de edad, sexo, médico asistente y fecha.

\section{Evaluación de factores de riesgo}

La hipótesis era la de un rol protectivo del tratamiento antibiótico, y por tanto consideraron como factor de protección el uso de antibióticos en el periodo analizado, corrigiendo los resultados para factores de riesgo clásicos (edad, dislipemia, consumo de tabaco)

\section{Medición de resultados principales}

Uso de antibióticos durante un periodo previo entre aquellos que desarrollaron o no un primer infarto.

\section{Resultados}

Los casos con infarto habían utilizado menos frecuentemente que los controles antibióticos: tetraciclinas (odds ratio 0.70 IC 95\% 0.550.90 ) y quinolonas (odds ratio ajustado 0.45 IC $95 \%$ 0.21-0.95). No encontraron relación entre el uso previo de macrólidos (eritromicina), sulfonamidas, penicilinas o cefalosporinas y el infarto. El uso crónico de aspirina o estrógenos también se asoció a una reducción del riesgo de infarto.

\section{Conclusiones}

Los resultados aportan evidencia indirecta a la asociación entre infección bacteriana por organismos susceptibles a la tetraciclina o quinolona y el riesgo de infarto agudo de miocardio. La reducción de riesgo con el tratamiento antibiótico sugeriría que el mismo, utilizado por motivos ocasionales, erradicó alguna infección que favorece el desarrollo de infarto.

\section{COMENTARIO}

Este estudio se ubica en el contexto del intento de definir un rol para la infección crónica y los antibióticos en la enfermedad aterosclerótica. Existen evidencias indirectas de asociación entre niveles de anticuerpos para Chlamydia pneumoniae y otros agentes (Helicobacter Pylori cepa patógena) y el desarrollo de enfermedad vascular, asi como entre niveles de PCR y enfermedad vascular ${ }^{1-2}$. La hipótesis consiste en pensar que la inflamacion crónica del endotelio favorece el desarrollo de aterosclerosis, y que esta inflamación es facilitada por un estado crónico activado de los macrófagos inducida por infecciones reiteradas por gérmenes como los citados, o que la infección genera modificaciones inmunológicas o locales en el mismo sentido. La confirmación del rol provendrá de estudios randomizados prospectivos que evalúen poblaciones grandes randomizadas a tratamiento con antibiótico vs control, varios de los cuales están en curso. Existen dos estudios con antibióticos en pacientes coronarios (posinfarto y angina inestable) con resultados positivos pero con pocos pacientes y aspectos que no se han confirmado en las etapas iniciales de los nuevos ensayos ${ }^{3-4}$. El estudio del JAMA aporta una información intrigante: haber sido tratado uno o mas veces con antibióticos durante pocos días reduciría en forma significativa la posibilidad de un evento coronario agudo. En los diseños prospectivos la mayoría de los autores propone tratamientos reiterados durante ciclos prolongados, habida cuenta de la alta frecuencia de reinfección con Chlamydia (tienen anticuerpos IgG positivos mas del $50 \%$ de la población adulta). A pesar de un diseño caso control, existen varios elementos que debilitan el resultado del trabajo: a) de los 7 grupos analizados con esquemas antibióticos, solo 2 tuvieron una reducción significativa, uno de los cuales abarcaba solo 8 casos y 62 controles y el otro 82 casos y 452 controles, sobre un total de 3315 infartos y 13139 controles; b) no se corrigieron los resultados para otras variables que pueden tener relación con la aparición de un infarto y que generan un conflicto lógico: es clásico que los pacientes infartados tienen una historia de ir poco al medico, por lo que el menor uso de antibióticos podría solo indicar que no concurren a la consulta frente a infecciones. Lo contrario, es decir que se infectan menos y por eso no requieren antibióticos, indicaría que las infecciones no son un factor de riesgo, lo que representa un contrasentido con el planteo del estudio. Una evidencia de esa actitud (health prone behaviour) de mayor cuidado en los no infartados es reflejada por el mayor uso preventivo de aspirina y de estrógenos. El estudio es acompañado de un editorial que finaliza con un comentario que creo adecuado resumir ${ }^{5}$ : "1) Se necesitan estudios grandes con antibióticos ... "; 2) Aun cuando sugieran un rol preventivo de la enfermedad aterosclerótica, el uso masivo de profilaxis podría inducir resistencias bacterianas con graves consecuencias epidemiológicas; 3) Por el momento, los médicos deben enfatizar el uso de las intervenciones que en forma probada previenen un primer infarto: hipolipemiantes, control de la hipertensión y cese del tabaquismo."

\section{Dr. Carlos Tajer}

Codirector de Gedic. Grupo para el estudio y la docencia de la investigación clínica. Jefe de Cardiología. Sanatorio de la Providencia.

\section{Referencias}

1. Gupta S, Camm AJ, Chlamidia Pneumoniae antibodies and coronary heart disease: coincidence, association, or causation? BMJ. 1997; 1778-1779

2. Gupta S, Leatham EW, Carrington D, et al. Elevated Chlamidia Pneumoniae antibodies, cardiovascular events, and azithromicin in male survivors of myocardial infarction. Circulation. 1997: 96: 404-407

3. Gurfinkel E, Bozovich G, Darocca A, et al. Randomised trial of roxithromicin in non Q wave coronary syndromes: R0XIS pilot study. Lancet. 1997;350: 404-407

4. Mattila KJ, Niemennen MS, Valtonen VV, et al. Association between dental health and acute myocardial infarction. BMJ. 1989; 298:779-781

5. Folson R Aaron. Antibiotics for prevention of myocardial infarction? Not yet! JAMA 1999: 281:461 